\title{
Deontology of New Testament tithing: An analysis
}

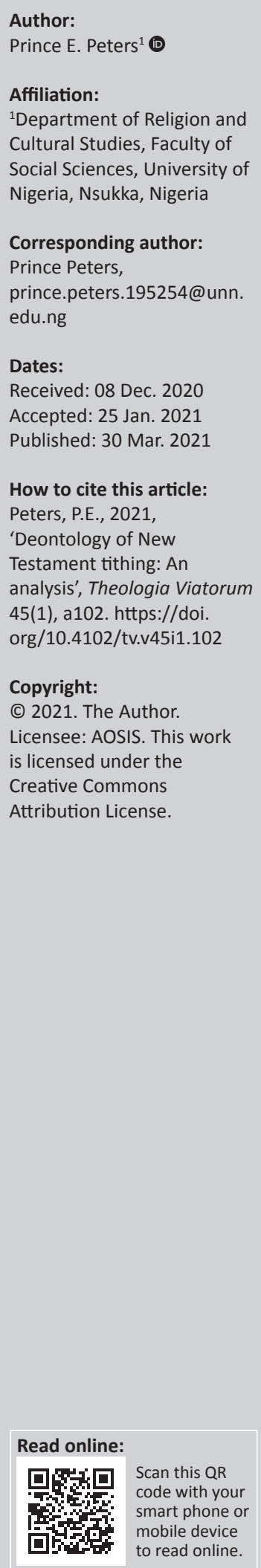

With the sudden heightened controversy surrounding tithing lately around the world, the subject of tithing deserves a critical analysis and a re-examination especially with regard to its ethical implications both in the New Testament text and the New Testament era. With the Rationality Theory applicable in the framework of Deontology and Form Criticism as its methodology, this study analysed New Testament texts that speak about tithe in line with their moral obligation as a duty both to the organised church and the poor congregants.

Keywords: tithe; New Testament; ethics; Mosaic law; Old Testament; Melchizedek; Abraham.

\section{Introduction}

Tithe (מַעִ the larger Christian responsibility of giving, has become an issue of serious controversy lately (Oluwoye 2013:2) probably because the church is at its "height of "prosperity" and "word of faith"' (Ajah 2013:107) theological euphoria.

In 2005 when the present author was a serving minister in the defunct Methodist Church Nigeria (MCN) (1962 Foundation Constitution), the superintendent minister, who he worked under, came to the pulpit one Sunday morning to 'counter' an age-long teaching upheld by MCN (1962 F.C). This age-long teaching was that tithe is not a New Testament practice. The church may have held to that opinion earlier on probably because 'John Wesley is[sic] a difficult figure in this debate' (Croteau 2005:18) who it appears gave less than a tithe in the first year of his ministry. ${ }^{1}$ The superintendent minister apologised to the church, almost kneeling down for misleading them into believing that tithe is no longer a New Testament doctrine.

'For far too long tithing has been treated as a "taboo" off-limits subject among many conservative churches. Too many informed seminary professors silently observe' (Russell 2007:1) whilst the battle rages on. It is obvious that 'there is some confusion on the subject' (Van der Merwe 2010:2). Whilst the study is not unaware of the dual challenge from teachings which claim that Christians under grace in the New Testament (NT) dispensation are not obligated to tithe like the Jews in the Old Testament (OT) and that Christian tithing is a hoax (Smith n.d.:online); the study's statement of problem therefore is as follows: what is the moral obligation of an NT Christian in the matter of tithing? For example, should Christians pay tithe as a moral obligation whether or not there is a direct command in the NT texts to make such a payment? Similarly, the study aims to enquire if the church has the moral obligation to use tithe to alleviate the sufferings of its congregants. Deontology, which is regarded in general as 'the study of moral obligation' (Nelson 1995:331), and considered particularly as a rational obligation towards a certain duty (here, the duty of tithe payment), is employed to understand the ethics of tithe payment, especially in contemporary Christianity. Form Critical method helped in understanding the various NT texts under study in their various sociological contexts, and Structuralist Critical method enables the comparison of ancient biblical texts with modern situations. To read more meanings into such passages with uncertain interpretations, sensus plenior ${ }^{2}$ was employed.

1.See Harshman (1905:79). Wesley's idea of tithing may have been misunderstood and misinterpreted over the years. Wesley's popular phrase 'Render unto God not a tenth' may have informed that Wesley never believed in payment of tithe. However, we should look phr it in the right cont at it in the right context, he said. 'Render unto God not a tenth, not a third, not half, but all that is God's (be it more or less)...' (Chervonenko 2017.65). The supposed understanding that Wesley always refers to 'a good Jew' only with reference to 'giving a tenth of all you possess' (Dang. of riches, II, 8; Boddie 2005:9) throws light that Wesley may have believed that tithing is mainly for the Jews.

2.Sensus plenior is that additional, deeper meaning, intended by God but not clearly intended by the human author, which is seen to exist in the words of a biblical text (or group of texts, or even a whole book) when they are studied in the light of further revelation or development in the understanding of revelation. Brown (1955:92) 


\section{The reflection of pre-Mosaic tithing in the New Testament}

There are arguments that Abel's gift to God was a tithe (Croteau 2005:31; Snoeberger 2000:73); therefore, Abel should be adjudged as the first man to pay a tithe to God. This idea seems to come from an unclear interpretation of the Genesis (4:7) account in the LXX (Croteau 2005:71-72). This is probably first propounded by Landsell (1955). The word which suggests a possible allusion to tithing in that passage is ' $j \mu \alpha \rho \tau \varepsilon \varsigma^{\prime}$ ['to dissect or divide] as against what is seen in the Masoretic Text '

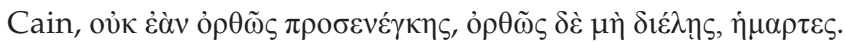
This question suggests that God's rejection of Cain's gift was because, although he brought the right gift, he was not able to divide it rightly by bringing out the right portion for God; this was a sin for Cain. Even though some scholars (e.g. Brenton 1986) have tried to study the said passage to see if truly it relates to tithing, it is doubtful that any biblical narrative compiled by the J redactors which concerns Cain and Abel's sacrifice especially Genesis (4:1.8) is tithe related for its obvious hermeneutical disconnect from other tithe passages. Some scholars have discussed the Cain and Abel saga, not as a tithe narrative, but as one related to Election (see Doukhan 2020:2; Duyndam 2008-2009:238; Orlov 2016:9). However, the context in which the narrative appears in the NT (Heb 11:4) is faith discourses (Kim 2016:130). The text refers to Abel's gift as $\theta v \sigma i ́ \alpha$ [sacrifice], which gained acceptance because it was of an excellent quality than Cain's and not a tithe in the current understanding. But then $\theta v \sigma i ́ \alpha$ being 'a part of all cultic religions' (Link \& Brown 1975:III, 415) includes first fruits - $\alpha \pi \alpha \rho \chi \eta$ - which renders מַעִ [tenth part or tithe] (Link \& Brown 1975:III, 416) and this leaves a wide opportunity to translate Abel's sacrifice as tithe.

Genesis (14:20) speaks about Abram's (Abraham) presentation to Melchizedek, the king of Salem and priest of God Most

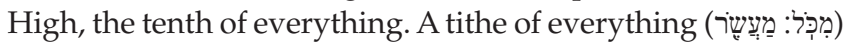
in the passage would include but is limited to everything that soldiers acquire as spoils of war which Abraham took away from them and subsequently owned.

The word translated 'everything' in that passage comes from the root verb כָָָּּ (kalal), which means 'to complete or perfect' which came to acquire the meaning of 'all'. This Abrahamic tithe is said to be 'in obedience to the Arab war custom' (Budiselić 2015:37; Kelly 2007:23). Two problems pose themselves in the text: first, the text is ambiguous (Croteau 2005:76), thereby presenting textual unclarity as to who gave tithe (one tenth) of everything to the other (Emerton 1971:407). This problem is basically because of the rabbinical interpretation of the passage which tends to suggest that Melchizedek and not Abraham gave one tenth (Dalgaard 2013:24). Even Jerome (Lett Lxxiii, 6) agrees that either Abraham or Melchizedek could be the recipient of the tithe because of the ambiguity of the text. However, R. H. Smith 3.This argument is advanced by Mark A. Snoeberger (2000:73).
(1965:129-152) suggests that the one paying the tithe was Melchizedek based on a parallel Ugaritic text, the Kirta legend. Again, there is also a case of clear uncertainty from the text that Abraham continued to pay tithe either to Melchizedek or to anyone else after the said event. But to the first problem, it is much more agreeable based on intrinsic probability that the tithe was paid by Abraham to Melchizedek chiefly because the passage records that

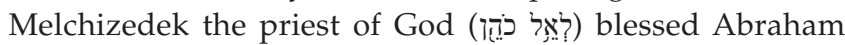
(Harris 1975:II, 694) a sign of the superiority of the office of Melchizedek to Abraham. This narrative is supported by the NT Hebrews (7:1,7). Westermann (1981:203) opines that

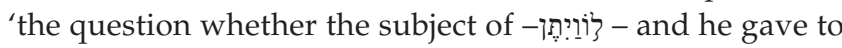
him - is Melchizedek or Abraham is to be answered from the structure of the whole, which is a cultic exchange'. Here, Smith's earlier assertion did not put into consideration that, in Ugarit, as well as other parts of the Ancient Near East, tithe belonged to kings and was received by kings only (Ajah 2006:32) and Melchizedek, not Abraham, was both the king and priest. On this same point, Emerton (1971:407-408) once again suggests that:

[S]ince the word translated 'tenth' ... is almost invariably used of a sacred payment, and since Melchizedek is said to be a priest, it is natural to suppose that he received the tithe and that Abram paid it.

In short, the Melchizedek-Abram passage is said to be added to 'reflect sedentary cult in which priest and tithes have their proper place' (Scullion 1992:3101). To the second challenge of uncertainty of Abraham's continued payment of tithe after the Melchizedek encounter, both the sociological condition behind the OT text and the life situation accompanying the NT exegesis on the said text do not reflect any possibility of continuity. However, archaeological findings suggest that the custom of paying a tithe, or tenth part, to the priesthood, or to the sanctuary, was very general in ancient times. Traces of it are found in Assyria and Babylonia. It also prevailed amongst the Greeks (see https://biblehub.com/commentaries/ pulpit/genesis/14.htm). It is therefore possible that the practice of paying tithes, primarily a voluntary tax $x^{4}$ for the servants of the sanctuary, appears to have been obtained amongst different nations from the remotest antiquity and was merely incorporated into the Mosaic laws at a much later date. It is even possible that tithe was not the only heathen practice culled from the nations and incorporated into the Levitical institution. Many scholars argue that the Levitical institution itself 'was borrowed strictly from early contemporary heathen practices'..$^{5}$ Arthur (1912:13-24) and Stewart (1903:7-13) seem to agree with Landsell that tithe was a well-known cultural practice in the earliest of cultures including that of the Greeks, Romans, Egyptians, Akkadians, Babylonians, Carthaginians, Silicians, Cretans, Phoenicians, Chinese and going as far back as the civilisations of the

4.Quoting 1 Samuel 8:10-17, Rodriguez (1994:82) mentions that a non-religious roya tithe (tax) was known in Israel. However for reference to religious tax outside Israel, see Hendriksen and Kistemaker (1995:187); and for non-religious tax outside Israel, see Anderson (1987:78-80).

5.Snoeberger (2000:72) cites Jagersma (1981:116-128) and Tate (1973:153). According to Snoeberger, included in this group are all those who view Israel's 'cultus' as evolutionary and not revelational. 
antediluvian age. ${ }^{6}$ Actually, these early civilisations are known because they are documented; however, there are civilisations that are not formally documented, and in such civilisations, oral tradition maintains its subsistence. For example, in Igbo civilisation, ndi mbu na ndi egede [the ancient people] told of the tale of the man Ojadili who wrestled and conquered the most violent and the best wrestling spirits. This heroic adventure of Ojadili made him the king of kings, who was only toppled by Chukwu [Almighty God]. Ojadili had seven priests who were considered the wise men (sages) and who were fed by the communal efforts of the people through one tenth of their wealth.

Based on the opinions of Arthur, Stewart and Landsell as cited earlier, it seems that what Abraham did was a normal practice (to which he must have practised several times in the past) and the writer of Genesis felt reluctant to elaborate on this practice probably because of the assumed commonality. This corroborates Davies' (1987:87) assertion that, as no elaboration is given concerning Abraham's gift, tithing must have been a common practice during Abraham's day. This may also answer the question of Abraham's continuity of the tithe. Abraham's tithe of everything may be the tithe pattern described by Lukan evangelist in Luke 18:12 because of the appearance of the construction $\pi \alpha v^{\prime} \tau \alpha . . . \kappa \tau \tilde{\omega} \mu \alpha$. In light of the scope of this article, Jacob's tithe, which is a narrative from the E source, shall not be discussed because of its nonreflection in the NT.

\section{Mosaic tithes and their New Testament implications The poor's tithe [Ma'aser 'Âni]}

In studying the various forms of tithe found in the Yahwist Elohist Deuteronomist Priestly (JEDP) documents (especially $P$ and D), this study omits tithe in Leviticus 27 because it 'is problematic in that it does not fit the description of either Numbers 18 or Deuteronomy 14' (Croteau 2005:91). In Deuteronomy 14:28-29 CEV, we are looking at the work of the $\mathrm{D}$ redactors concerning tithe, what some have come to call the third tithe (Köstenberger \& Croteau 2006:63), with verses 22-27 containing the second. Some others, like De Vaux (1997:141-142) and Murray (2002:76), have even tried justifying its uniqueness by mentioning its distinct characteristics. To those who feel it falls in the third type, the tithe document of the P school in Numbers 18 is the first. However, some others see what is called second and third as one as well as the second in tithe classification, whilst the tithe document in Numbers remains the first (https:// biblehub.com/commentaries/ellicott/deuteronomy/14. $\mathrm{htm})$. Of course, a closer look at the earlier two classifications suggests that it is unnecessary, and could be the error of poor redaction. For simplification purposes, Ma'aser 'Âni shall be called the second tithe. From the opening text, it can be seen

6.See Snoeberger (2000:71), who according to Köstenberger et al. (2006) lists the Roman, Greek, Carthaginian, Cretan, Sicilian, Phoenician, Chinese, Babylonian, Roman, Greek, Carthaginian, Cretan, Sicilian, Phoenician, Chinese, Babylonian,
Akkadian and Egyptian cultures as ones who had some form of tithing. See also Akkadian and Egyptian cultures as ones who had
Jagersma (1981:78-79) and Weinfeld (1971:1155). that the D school believed that the Ma'aser 'Âni was not for the Levites and priests only; it was also for those who were handicapped and incapacitated by being landless, and this could be the reason why Croteau (2005:34) calls it 'the charity tithe'. But it is very important to explain that this kind of tithe (although the Levites can partake in it through the magnanimity of the one who pays the tithe), however, is totally different from that which the Levites received from the people, which is documented by the $\mathrm{P}$ redactors and mainly contained in Numbers, chapter 18. Ma'aser 'Âni is strictly an opportunity for those who cannot fend or provide for themselves for the major reason that they were landless to still join in the celebration of fruitful harvest. This kind of tithe is enjoyed every 3 years - Ant. iv, 4.3; Tobit 1:7-8 - (i.e. the 3rd and 6th years of each 7-year cycle-Sanders 1992:5213). With time in Israel, it seems that $M a$ 'aser 'Âni disappeared from the religious scene and was replaced with organised charity from the kuppah - charity fund (Rabinowitz 2008:online). Since its disappearance from the religious scene in Israel took effect even before the NT era, it is hardly possible that it was ever reflected in any Christian traditions. Considering that it was precisely in Ma'aser 'Âni that the moral and ritual overlap of OT tithe becomes prominent - by its provision for charity outside the priesthood - it suggests for a re-institution or an engrafting of this tithe system into the Levitical tithe system which currently dominates Christian liturgy, for the entrenching of sound ethical values in modern tithing. When Jesus criticised the Pharisees in Matthew 23:23, although they paid their tithe by law, but neglected the $\beta \alpha \rho v i \varepsilon \rho \alpha$ [heavier part] of the same law, it carries the implication that the law Jesus refers to was the tithe law of which the Pharisees unfortunately fulfilled half of it (the ritual) and neglected the other half (ethical

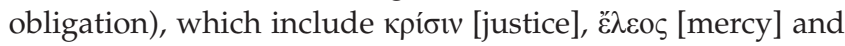
$\pi i ́ \sigma \tau$ [faithfulness] - moral attributes needed to see the wellbeing of the less privileged in the community.

\section{Tithe for the Levites}

The tithe represented in Numbers 18:24-29 NLT is the socalled first tithe that Yahweh discussed. This tithe as contained in the above-mentioned passage is given to the

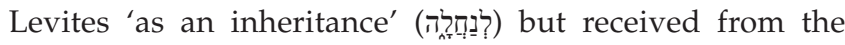
hands of the children of Israel. The Levites inherited the tithe primarily because of the service they rendered to the children of Israel which is 'to do the service of the tabernacle of the congregation and to bear their (the Israelite's) iniquity' (Nm 18:23), and mainly because they were not meant to hold 'personal' landed property. The Israelites were given the land of Canaan by Yahweh but the Levites were not to inherit any direct property, and therefore their heritage from Yahweh was 'all' (-כָָּ) of the tithe of the children of Israel. The study should do well at this juncture to explain that certain translations like English Standard Version (ESV) and Christian Standard Bible (CSB) which replaced 'all' with 'every' in that P document (Nm 18:21) could plunge the entire narrative into a mistranslation because 'every' would broaden the tithe scope in this passage to include even the two other kinds of tithe 
contained in the D document. Another peculiarity of this tithe was that, out of it, the Levites would pay the priests (the sons of Aaron) a tithe, the best of what they got from the whole house of Israel. The beauty here is that this is the only tithe commanded by Yahweh to be exclusively used by those who do the temple service. Indeed, this kind of tithe follows the style of what obtains in almost all brands of Christianity today.

\section{Malachi 3:6-10 discourses on tithe}

The book of Malachi is grouped under the very broad 'prophecy' genre (Everett 2018:9). However, a close study would indicate that it is precisely kerygmatic apocalypsis. It seems to follow D document in its legal interpretations instead of P (Hill 1992:5528). Its composition was circa 430 $\mathrm{BC}^{7}$ by the prophet Malachi (Everett 2018:7). ${ }^{8}$ It is the 'concluding book' (Martin 2014:2) of the minor books of the prophets contained in the Hebrew Bible. The theology of Malachi is primarily care for Yahweh's sanctuary (Fischer 2012:133-138). On the fifth oracle which deals with tithe and offerings, Malachi justly reminds the people of their flagrant disobedience to God's instruction, which they seem not to be aware of. They took (robbed) God's tithe and offerings by not giving in full. The context of the passage suggests that the tithe that Malachi accused the people of robbing God was the one contained in Numbers 18:21-29, which was called the 'tithe for the Levites'. Whilst the 'offering' in that text could be the heave offering, the breast and shoulder of the peace offering were the priests' portions. It will be recalled that during the return from exile, Nehemiah (10:3239) took the attention of the people to the temple, its worship, including the maintenance of the priests and the Levites who served along with them through tithe and various offerings (see Willmington 2018:5). Here Nehemiah (10:38) instructs them on how the Levites will collect the tithe (which is theirs by right) and forward the tithe of tithes (which belonged to the priests) to the treasure house or store house. With the application of Structuralist Critical method to Malachi, there is a new awareness that the priestly cult in Jerusalem and the storehouse phenomenon went hand in hand and were inseparable from the second temple period. Whilst in its application we see the priestly cult existing in vague form in the contemporary Christian clerical calling, the storehouse also must exist in the form of church treasury, from where the current Levites (church workers) and priests (pastors) must feed. Because 'one of the fundamental structuralist principles used to interpret all empirical forms of social behaviour and their deep structures is the principle of binary opposition' (Hayes \& Holladay 1934:115), there is therefore a strong assertion that the priestly cult of selflessness and the Levitical calling of landlessness pairs in opposition to a storehouse of wealth, riches and gaiety.

7.Some scholars propose different dates for its composition. For example, Longman III and Dillard (2006:498) propose 475-450 BC; Spoer (1908:167) dates it to the period of Ezra and Nehemiah, the Persian period.

8. Martin (2014:5) argues that 'Malachi, according to the Jews, is a title, not a man's name'. Malachi means 'my messenger'. It was applied to John the Baptist later as the 'messenger of God'. Anyone who is a 'messenger of God' can be called a malachi. It is like an angel is a 'malacha' or a king in Hebrew is a melek.

\section{Active and passive discourse on tithe in the New Testament}

Matthew 23:23 and Luke 11:42, 18:9-12 are the only passages in the gospels that spoke about tithe. Additionally, in the rest of the NT, Hebrews 7:1-10 speaks about it too. In all these passages, Jesus made implied statements, none had the discourse on tithe as the primary subject and because of this Sensus plenior must be employed. In the Q text (Lk 11:42/ / Mt 23:23), Jesus' statement was to the Scribes and Pharisees whom he pronounced 'woes' upon. On the first woe, he accused them of being so superstitious as to observe the minutest of the law by extension, tithing. They gave tithe of the smallest plants in Israel which included mint, anise and cumin. It should be recalled that mint, anise and cumin were garden seeds of small nature with aromatic flavour. They were 'marketable commodities, used as condiments or for medicinal purposes' (https:/ / biblehub.com/commentaries/ egt/matthew/23.htm). There is no data to argue that Jesus attacked the Pharisees for tithing irrelevant things (it is likely that the rabbinic laws accommodated even herbs - Jacobs n.d.). Again, it has also been argued that Jesus' attack against the Pharisees in the text does not suggest that he opposed tithe (Davies 1987:88-89). Jesus' anger on the Pharisees was their extreme scrupulousness which led to self-righteousness (see Rodriguez 1994:46). The passage itself gives some insights into Jesus' position about tithe: (1) Jesus considered the kind of tithe obtainable in his time as a continuity of OT laws. This position hardly suggests that Jesus saw tithe as part of the fulfilled and abrogated laws, it rather suggests that it was one of those legal practices that should not take precedence in the religious life of an average Jew. In fact, the great zeal to pay tithe by those Jews was an outward zeal of an inward rotten religious life (Dosker 1915:458). The 'Jew' is mentioned here because the original audience in that narrative were Jews and not Messianists. One is here enabled to understand that Jesus' point was that religious observances like tithing were good (Budiselić 2014:34) - the last part of the verse indicates that Jesus approved tithe - (Köstenberger:19; Wilson 1967:357), but fulfilling the law of righteousness which would include the conversion of the legalistic observance to practical moral display was better and in fact takes precedence. (2) Because the very words of Jesus on this subject are contained in a Christian text, the application extends to Christians by implication owing to the fact that the evangelists wrote those words primarily for their various gospel communities. Here, it can be argued that Jesus gave a reason as to why payment of tithe should not be dismissed as a Jewish ritual, rather one that equally affects Christians (because Jesus neither frowned at the practice nor condemned it). Hence, 'Jesus does not prohibit tithing; he condemns the wrong attitude and motive of those who were tithing' (Croteau 2005:125), which was to exclude the moral obligation of tithing from the practice itself.

Luke's account of a two-point parable (18:9-12) (see Blomberg 1990:257-258) just like the previous Q text is itself not a teaching on tithe by Jesus, rather it is a teaching on humility which is more pleasing to God than a haughty and perfunctory 
performance of religious duties. However, tithing is inferred. The haughtiness of the Pharisee who prided himself in his righteousness turns to an abomination before God not because he reminded God of his righteous deeds but because he took ostentation as a duty (Culpepper 1983:340). He reminded God of his twice a week (Mondays and Thursdays) fasting, a practice without in fact divine sanction in ancient Israel (https://biblehub.com/commentaries/ pulpit/luke/18.htm). At the same time, his empty ceremonialism widened to include his tithe of thoroughness which infuriated Jesus. On the part of the $\tau \varepsilon \lambda \omega \operatorname{v\eta } \varsigma$ [tax collector], his job alone is offensive to the Jew who sees him as being in league with Rome to put the Jews to forced labour and taxation. Consequently, a tax collector was one of the basest of men with no moral rectitude who cannot even bring his tithe to the temple. It appears that the Jews in Jesus' time saw whoever that enforces Rome's servitude as defiled (see Dt 23:18) and so should not be allowed, and neither their gifts, into the temple. The tithe implication from the text then is that whilst Jesus did not teach tithing, he at the same time did not condemn it. Wilson (1992:578-580) is of the opinion that tithes receive very little attention in the NT, whilst Coetzee (1992:26-27) argues that 'we read nowhere that Jesus and his disciples cancelled the bringing of the tithe'.

Hebrews (7:1-10) gives an occasion to discuss tithing outside the gospels. This discourse which has no parallel in any biblical literature introduces a mysterious figure. According

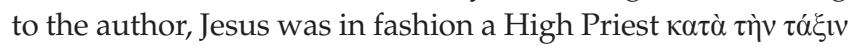

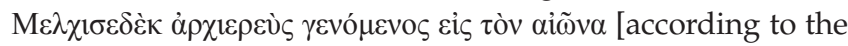
order of Melchizedek right through the age or forever]. Meyer (https:/ / biblehub.com/commentaries/meyer/hebrews/7. $\mathrm{htm})$ explains that by delineation of the character of Melchizedek Hebrews 7:1-3 forms a single proposition, in which $\mu \varepsilon \dot{v \varepsilon l, ~[h e ~ r e m a i n s] ~ i s ~ t h e ~ t e m p u s ~ f i n i t u m . ~ W h o ~ w a s ~}$ Melchizedek? Apart from the knowledge that his name means the king of righteousness, no doubt it can also mean 'my king is Zedek' (Van der Toorn et al. 1996:560) (a meaning that the church may have hidden especially since the name 'Melchizedek' has 'entered the canon of the Roman mass') (seehttps:/ / www.britannica.com/biography/ Melchizedek). The scripture said he was the king of Salem, which means 'peace', and had no record of a father or mother (Finkbeiner 2017:108). Does this suggest that he was a theophany? ${ }^{9}$ The Melchizedek's tithe narrative, just like Jacob's tithe narrative, could be unhistorical (Wilson 1992:8962) but if we assume that it is historical, then he had a real personage. As a real figure, Melchizedek must be the contemporary of Abraham, which disassociates him from Shem ${ }^{10}$. It seems that the two perfect indicative verbs in

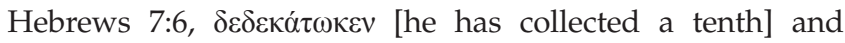

9.Some interpreters have thought that Melchizedek in Genesis $14: 18-20$ is a preincarnate appearance of Christ, mostly on the basis of what Hebrews 7:1-3 says. But He is both the king and the priest; the lack of mention of genea is a type of Christ. He is both the king and the priest; the lack of mention of genealogy shows that his priesthood does not depend on tribal descent; the lack of mention of his beginnin 2018:257).

10.A long-standing rabbinic tradition differed from the Christian innovation and identified Melchizedek with biblical character of Shem, the son of Noah (Kuehn 2010:510-571).

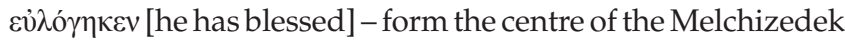
discourse in the passage (Heath 2011:192), yet there is no implication that the writer of Hebrews presents tithing as an NT practice or an OT norm which must be maintained in the new era.

\section{Moral obligation in the ritual 'tithe' within the New Testament church}

The trace of tithing through the pre-Mosaic to the NT text in this study is to prove that there are no textual or historical evidence of NT tithing either as an instruction or as a practice throughout the 1st century Christianity. In fact, it has been argued that the practice of tithing started as a child of necessity by the Early Church Fathers, after the cost of maintaining the church became unbearable (Nwokoro 2007:30). However, tithe was not forbidden or criticised by Jesus. Moreover, history has established that there are many traditions in Christianity which, although not explicitly found in the Bible, enjoys a pride of place in church teachings; tithe should enjoy more than a pride of place for being a part of Christian tradition for over 1000 years ${ }^{11}$ and also for being implied by Jesus himself; not forgetting that it has solved obvious ecclesiological and missiological problems over the years. The Pentecostal churches in Africa are prospering because of people's faithfulness in payment of tithe; Christian missions are doing well on the international scene courtesy of tithe (Ehioghae 2012:144). But the practice has received much criticism from practising Christians who call it 'extortion'.

Some have argued that with regard to the brand of tithe taught in Malachi 3:8-12, it is limited to farmers only who have land to the exclusion of others (Ademiluka 2020:301). Whilst the context of the Malachi passage gives room to assume that the material required for tithing was agrarian products (plants and animals), it should be borne in mind that revelation is progressive and the essence of hermeneutics is the application of interpretation gotten from ancient texts and cultural practices to the contemporary times. One does not expect Joshua to fight all the wars to establish the 12 tribes on the Promised Land with modern war machines and ammunitions, neither does one expect Paul to travel on his missionary journeys in modern fast cars and marine vessels. In the same vein, the culture upon which the instruction to tithe was given was an agrarian culture and the major products for commerce and industry were also agrarian. There are two moral obligations for which every faithful should pay tithe; one is that 'there may be meat in mine house'. Such provision takes care of the daily sacrifices in the temple and the personal needs of the priests and Levites who serve in the temple. This does not include wastages and extravagance from the priests and Levites. Such provision from tithe was to satisfy their immediate needs. Jesus taught clearly on the disapproval of the Father to wastages and extravagance (Mk 6:43) and it is an abuse of office for pastors to flagrantly display wealth gotten from tithes and offerings as some are seen to do (see Kitause \& Achunike 2013:7). The 11.Cross (1957:1626) argues that the payment of tithe has enjoyed a pride of place in Christian tradition since the 4 th century. 
fact that an advocacy has been made that priests and Levites were given tithe in OT because they had no land and the present clergy are not denied access to own landed property, and so should not collect tithe, is a one-sided argument because it does not consider that tithe in the OT was compulsory in order to adequately carter for the needs of the entire landless priesthood. In a dispensation where tithe is not compulsory and the government does not give out land for free to the clergy to farm on, tithe is definitely required as a rational measure. However, if tithe should be collected by the church, the church should consider humanitarian services to the poor through tithe; as argued earlier on, this is the second ethical angle that must become prominent. The call to consider the poor as a moral obligation from tithe is mainly fuelled by two factors: the economic downturn amongst Christian faithful especially in Africa and the unfortunate extravagant lifestyle of church clergy. Furthermore, to successfully continue the tradition of tithing in the present church would naturally require that the church ceases to place curses upon whosoever did not pay. Such threats, if it ever existed in the Bible, were within the reins of the OT when it was compulsory and mandatory under law to pay tithe. The present author once saw a video clip of a Nigerian pastor who declared that 'anyone who did not pay tithe will go to hell fire, period'. Such lies and threats arise from ignorance. Whilst such pastors command large followership, sadly they have little or no theological knowledge.

\section{Conclusion}

There are no tithe passages in the NT; however, the Bible with no exception to the NT does not frown at the payment of tithe. Rightly said, tithe was a lawfully obligatory responsibility of every Israelite in the OT; it carried no such import in the NT, but Jesus' implied statement about tithe itself including its practice as a church tradition gives it a pride of place in Christian practice. However, the moral obligation of tithing has long been partially implemented by using the proceeds to take care of the church without care for the poor and the less privileged. This article argues that all moral obligations accruable to the practice of tithing should be upheld without discrimination.

\section{Acknowledgements Competing interests}

The author declares that they have no financial or personal relationships that may have inappropriately influenced them in writing this article.

\section{Author's contribution}

P.E.P. is the sole author of this research article.

\section{Ethical considerations}

This article followed all ethical standards for research without direct contact with human or animal subjects.

\section{Funding information}

This research received no specific grant from any funding agency in the public, commercial or not-for-profit sectors.

\section{Data availability}

The author confirms that the data supporting the findings of this study are available within the article.

\section{Disclaimer}

The views and opinions expressed in this article are those of the author and do not necessarily reflect the official policy or position of any affiliated agency of the author.

\section{References}

Ademiluka, S.O., 2020, 'A study of Malachi 3:8-12 in relation to tithing in some churches in Nigeria', OTE 33(2), 285-305. https://doi.org/10.17159/2312$3621 / 2020 / v 33 n 2 a 8$

Ajah, M., 2006, 'Tithing in Ugarit and the Pentateuch - Possible implications for Africa', Scriptura 91, 31-42. https://doi.org/10.7833/91-0-1100

Ajah, M., 2013, 'The significance of Pentateuchal tithing as a legal instruction for the 21st century reader', The Asbury Journal 68(2), 106-119.

Anderson, G.A., 1987, Sacrifices and offerings in ancient Israel, Scholars Press, Atlanta, GA. Arthur, B., 1912, The law of the tithe as set forth in the Old Testament, Revell, New York, NY.

Blomberg, C.L., 1990, Interpreting the parables, InterVarsity, Downers Grove, IL.

Boddie, S.C., 2005, Way to give: Tithing practices that benefit families, congregations, and communities, Washington University in St. Louis, George Warren Brown School of Social Work: Center for Social Development, St Louis, MO

Brenton, L.C.L., 1986 \& 2007, The Septuagint with apocrypha: Greek and English, Hendrickson Publishers, Peabody, MA. 1986 \& NETS 2007. Oxford University Press, New York, NY. Electronic edition, viewed 07 August 2020, from http://ccat. sas.upen.edu/nets.

Brown, R.E., 1955, The Sensus Plenior of sacred scripture, St. Mary's University, Baltimore, MD.

Budiselić, E., 2014, 'The role and place of tithing in the context of Christian giving part 2', KAIROS - Evangelical Journal of Theology IX(1), 31-58.

Budiselić, E., 2015, 'The Role and Place of Tithing in the Context of Christian Giving Part 2', KAIROS - Evangelical Journal of Theology 9(1), 31-58.

Chervonenko, S., 2017, 'Stewardship in the church: The theology and practice of tithing, offerings, and stewardship in evangelical churches of Russia', unpublished Doctor of Ministry dissertation, Asbury Theological Seminary.

Coetzee, P.J., 1992, 'Gee u ook u oorskiet aan die Here?', Die Kerkblad, 11 Maart, pp. 26-27.

Cross, F.L., 1957, The Oxford dictionary of the christian Church, Oxford University Press, Oxford

Croteau, D.A., 2005, 'A Biblical and theological analysis of tithing: Toward a theology of giving in the new covenant era', A published Doctor of Philosophy Dissertation, Presented to the Faculty of Southeastern Baptist Theological Seminary Wake Forest, NC.

Culpepper, R.A., 1983, Anatomy of the fourth Gospel: A study in literary design, Fortress, Philadelphia, PA.

Dalgaard, K., 2013, A priest for all generations: An investigation into the use of the Melchizedek figure from Genesis to the Cave of Treasures, Det Teologiske Fakultet. Publikationer fra Det Teologiske Fakultet, København, Bind. 48

Davies, G.B., 1987, 'Are Christians supposed to tithe?', Criswell Theological Review 2(1), 85-97.

De Vaux, R., 1997, Ancient Israel: Its life and institutions, transl. J. McHugh, WM. B. Eerdmans Publishing \& Dove Booksellers, Grand Rapids, MI.

Dosker, H.E., 1915, 'Between the Testaments', in J. Orr (Gen. ed.), The international standard Bible encyclopedia, pp. 455-458, The Howard-Severance, Chicago, IL.

Doukhan, D., 2020, 'Cain and Abel: Re-Imagining the immigration "Crisis"', Religions 11(112), 1-12. https://doi.org/10.3390/rel11030112

Duyndam, J., 2008-2009, 'Girard and Levinas, Cain and Abel, Mimesis and the face', Contagion: Journal of Violence, Mimesis, and Culture 15/16, 235-246. https://doi. org/10.1353/ctn.0.0023

Ehioghae, E.M., 2012, 'Tithing and the quest for material prosperity: A critical evaluation of contemporary trends in Nigerian Pentecostalism', AAMM 6, 143-160.

Emerton, J.A., 1971, 'The riddle of Genesis XIV (rev.)', Vetus Testamentum 21(4), 403-439. https://doi.org/10.1163/156853371X00308 
Everett, G.H., 2018, Study notes on the Holy Scriptures: Using a theme-based approach to identify literary structures, The book of Malachi, January 2018 Edition, s.n., s.l.

Finkbeiner, J., 2017, The Priests of God: Unveiling the order of Melchizedek, Booklocker, St. Petersburg, FL.

Fischer, G., 2012, Theologien des Alten Testaments, NSKAT 31, Verlag Katholisches Bibelwerk $\mathrm{GmbH}$, Stuttgart.

Harris, M.J., 1975, 'Tithe', in C. Brown (ed.), The New International Dictionary of New Testament Theology, pp. III, 415-417, The Zondervan Corporation, Grand Rapids, MI.

Harshman, C.W., 1905, Christian giving, Eaton and Mains, New York, NY.

Hayes, J.H. \& Holladay, C.R., 1934, Biblical exegesis: A beginner's handbook, John Knox Press, Atlanta, GA.

Heath, D.M., 2011, 'Chiastic structures in Hebrews: A study of form and function in Biblical discourse', Unpublished dissertation presented for the degree of Doctor of Philosophy in Biblical Languages at the University of Stellenbosch

Hendriksen, W. \& Kistemaker, S.J., 1995, New Testament commentary: Exposition of Thessalonians, the Pastorals, and Hebrews, Baker, Grand Rapids, MI.

Hill, A.E., 1992, 'Book of Malachi', in D.N. Freedman (Gen. ed.), The Anchor Bible Dictionary, pp. 5525-5534, Doubleday, New York, NY.

Jacobs, L., n.d., Tithing, viewed 07 August 2020, from https://www.myjewishlearning. com/article/tithing/.

Jagersma, H., 1981, 'The tithes in the Old Testament', in B. Albrekston \& O. Rotem (eds.), Remembering al the way: A collection of Old Testament studies published on the occasion of the fortieth anniversary of the Oudtestamentisch Werkgezelschap in Nederland, pp. 116-128, Brill, Leiden.

Kelly, R.E., 2007, Should the church teach tithing? Writers Club Press, Lincoln.

Kim, K.S., 2016, 'Better than the blood of Abel?' Tyndale Bulletin 67(1), 127-136.

Kitause, R.H. \& Achunike, H.C., 2013, 'A historical discourse on tithing and seed sowing in some Nigerian Pentecostal churches', IOSR Journal Of Humanities And Socia Science 18(3), 7-19. https://doi.org/10.9790/0837-1830719

Kostenberger, A., 2006, '(Malachi 3:8): A study of tithing in the Old and New Testaments', viewed 06 December 2018, from https://korycapps.files.wordpress. com/2012/11/a-kostenberger-tithing-in-ot-and-nt.pdf.

Köstenberger, A.J. \& Croteau, D.A., 2006. “"Will a man rob God?” (Malachi 3:8): A study of tithing in the Old and New Testaments', Bulletin for Biblical Research 16(1), 53-77.

Kuehn, E.F., 2010, 'Melchizedek as exemplar for kingship in twelfth-century political thought', History of Political Thought 31(4), 557-575.

Landsell, H., 1955. The sacred tenth or studies of tithe-giving, ancient and modern 2 vols., Baker, Grand Rapids, MI, 1:56

Link, H.G. \& Brown, C., 1975, 'Sacrifice' in C. Brown (ed.), The New International Dictionary of New Testament Theology, pp. III, 415-417, The Zondervan Corporation, Grand Rapids, MI.

Longman, III, T. \& Dillard, R.B., 2006, An introduction to the Old Testament, Zondervan, Grand Rapids, MI.

Martin, E.L., 2014, 'The book of Malachi', Associates for Scriptural Knowledge 6(14), 1-12.

Murray, S., 2002, Beyond tithing, Paternoster, Carlisle.

Nelson, M.T., 1995, 'Deontology', in D.J. Atkinson \& D.H. Field (ed.), New dictionary of Christian ethics and pastoral theology, pp. 331-332, Intervarsity Press, Leicester.
Nwokoro, I.N., 2007, Tithe: The history and benefits, Chriso Printers, Lokoja.

Oluwoye, J.O., 2013, 'Ethical evaluation of tithes and offerings in Osun Baptist Conference, Nigeria', An unpublished Thesis in the Department of Religious Studies, submitted to the Faculty of Arts for the award of Doctor of Philosophy.

Orlov, A., 2016, 'The Atoning Dyad: The two goats of Yom Kippur in the apocalypse of Abraham', Studia Judaeoslavica 8, 1-72. https://doi.org/10.1163/9789004308220

Poythress, V.S., 2018, Theophany: A Biblical theology of God's appearing, Crossway, Wheaton, IL.

Pulpit Commentary, 2010, viewed 06 August 2020, from https://biblehub.com/ genesis/28-22.htm.

Rabinowitz, L.I., 2008, 'Begging and beggars', Jewish Virtual Library, viewed 07 August 2020, from https://www.jewishvirtuallibrary.org/begging-and-beggars.

Rodriguez, A.M., 1994, 'Stewardship roots: Toward a theology of stewardship, tithe and offerings', in General Conference of Seventh-day Adventists, Cohutta Springs, GA, United States of America, March 20, 1994, pp. 1-89.

Russell, E.K. 2007, Should the church teach tithing? A Theologian's conclusions about a taboo doctrine, Writers Club Press, New York, NY.

Sanders, E.P., 1992, 'Law in Judaism of the NT period', in D.N. Freedman (Gen. ed.), The Anchor Bible Dictionary, pp. 5210-5225, Doubleday, New York, NY.

Scullion, J.J., 1992, 'The narrative of Genesis', in D.N. Freedman (Gen. ed.), The Anchor Bible Dictionary, pp. 3088-3108, Doubleday, New York, NY.

Smith, L.R., n.d., Tithing is unscriptural under the New Covenant [A scriptural exposition on the fraudulent fleecing of the flock], viewed 06 December 2018, from https://bible-truths.com/tithing.html.

Smith, R.H., 1965, 'Abram and Melchizedek (Gen 14.18-20)', ZAW 77, 129-152. https://doi.org/10.1515/zatw.1965.77.2.129

Snoeberger, M.A., 2000, 'The pre-Mosaic tithe: Issues and implications', Detroit Baptist Seminary Journal 5(Fall), 71-95.

Spoer, H.H., 1908, 'Some new considerations towards the dating of the Book of Malachi', Jewish Quarterly Review 20, 167-186.

Stewart, E.B., 1903, The tithe, Winona Publishing Co., Chicago, IL.

Tate, M.E., 1973, 'Tithing: Legalism or benchmark?', Review and Expositor 70(Spring), 153-161. https://doi.org/10.1177/003463737307000203

Van Der Merwe, J.A.I., 2010, 'An exegetical and theological study of Malachi 3:8-12 and its implications for Christians, with particular reference to Tithing', unpublished Master of Theology thesis, South African Theological Seminary.

Van Der Toorn, K., Becking, B. \& Van der Horst, P.W., 1996, Dictionary of Deities and Demons in the Bible, William B. Eerdmans Publishing, Grand Rapids, MI.

Weinfeld, M., 1971, sv 'Tithes', EJ 15, 1155-1163. https://doi.org/10.1016/00134686(70)85009-5

Westermann, C., 1981, Genesis 12-36, SPCK, London.

Willmington, H., 2018, 'The Chapters of Nehemiah', in An alliterated outline for the chapters of the Bible, 35, viewed 07 August 2020, from http://digitalcommons. liberty.edu/outline_chapters_bible/35.

Wilson, J.C., 1992, 'Tithe', in D.N. Freedman (ed.), The Anchor Bible Dictionary, vol. 4, K-N., Doubleday Dell, New York, NY.

Wilson, L., 1967, 'The Old Testament and tithe', in Baker's dictionary of practical theology, Baker Book House, Grand Rapids, MI. 